\title{
Toll-like receptor 7 rs179008/GIn11Leu Gene Variants in Chronic Hepatitis C Virus Infection
}

\begin{tabular}{|c|c|}
\hline Journal: & Journal of Medical Virology \\
\hline Manuscript ID: & JMV-10-1860.R1 \\
\hline Wiley - Manuscript type: & Research Article \\
\hline $\begin{array}{r}\text { Date Submitted by the } \\
\text { Author: }\end{array}$ & 30-May-2010 \\
\hline Complete List of Authors: & $\begin{array}{l}\text { Askar, Eva; University Medical Center Goettingen, Department of } \\
\text { Gastroenterology and Endocrinology } \\
\text { Ramadori, Giuliano; University Medical Center Goettingen, } \\
\text { Department of Gastroenterology and Endocrinology } \\
\text { Mihm, Sabine; University Medical Center Goettingen, Department of } \\
\text { Gastroenterology and Endocrinology }\end{array}$ \\
\hline Keywords: & $\begin{array}{l}\text { Toll-like receptor } 7 \text { (TLR7), single-stranded RNA (SSRNA), hepatitis } \\
\mathrm{C} \text { virus (HCV), single nucleotide polymorphism (SNP), portal } \\
\text { lymphoid aggregates }\end{array}$ \\
\hline
\end{tabular}

\section{S) ScholaroNE \\ Manuscript Central}


Toll-like receptor 7 rs179008/GIn11Leu Gene Variants in Chronic Hepatitis C Virus 3

\section{Infection}

4

5

Eva Askar, Giuliano Ramadori, Sabine Mihm

8

Department of Gastroenterology and Endocrinology, University Medical Center,

9

Georg-August-University, D-37075 Goettingen, Germany

10

11

12 Running title: TLR7 gene variants in chronic hepatitis C

13

14

15

16

17

18 Correspondence to:

19 Sabine Mihm, Prof. Dr. rer. nat., Department of Gastroenterology and Endocrinology,

20 University Medical Center Goettingen, Robert-Koch-Straße 40, 37075 Goettingen, Germany,

21 e-mail:smihm@med.uni-goettingen,de

22 Phone: +49-551-398946 Fax: +49-551-397855 


\section{ABSTRACT}

24

25

Hepatitis $\mathrm{C}$ virus (HCV) infection affects an estimated 3\% of the world's population. The natural outcome of infection and the natural course of disease are highly variable. Sensing of viral single-stranded RNA (ssRNA) by Toll-like receptor 7 (TLR7) is likely involved in early pathogen detection and host response to viral infections. This study analyzed epidemiological and clinical data from 136 patients with HCV infection with regard to rs179008/Gln11Leu, a non-synonymous polymorphism within exon 3 of the X-linked TLR7 gene, the variant allele of which is suggested to code for a functionally impaired protein. Allele-specific transcript quantification (ASTQ) analyses in heterozygous females revealed individual skewed mosaicism in peripheral blood mononuclear cells (PBMCs). Thus, analyses were restricted to homo- and hemizygous individuals. Among the clinical and histological parameters studied, the variant allele $\mathrm{T}$ was found to be solely associated with the presence of portal lymphoid aggregates. Whereas hepatic viral load and expression of genes known to be induced in chronic HCV infection were not found to differ in patients with wildtype or variant TLR7 rs179008 genotype, significant lower gene expression of interleukin-29 (IL-29)/lambda 1 interferon (IFN- $\left.\lambda_{1}\right)$ and both of its receptor subunits was found for T homo- and hemizygous patients. Irrespective of the minor differences in disease phenotype including hepatic viral load, natural and alpha interferon (IFN- $\alpha$ )-mediated outcome of infection, and disease activity and progression, the significant differences in hepatic IL-29/IFN- $\lambda_{1}$ and IFN- $\lambda$ receptor gene expression between TLR7 rs179008 $\mathrm{T}$ and A allele patients might have implications for responsiveness to future IFN- $\lambda$-based approaches.

KEYS WORDS: Toll-like receptor7 (TLR7); single-stranded RNA (ssRNA); hepatitis C virus (HCV); single nucleotide polymorphism (SNP); portal lymphoid aggregates 


\section{INTRODUCTION}

Chronic infection caused by hepatitis $\mathrm{C}$ virus $(\mathrm{HCV})$, an enveloped single-stranded RNA (ssRNA) virus [Choo et al., 1989], develops in 70\%-80\% of patients [Schwabe et al., 2006].

Patients are at a high risk of developing severe disease as liver cirrhosis and hepatocellular carcinoma [Schwabe et al., 2006]. Toll-like receptors (TLRs) play a critical role in the innate immune sensing of the invasion of pathogenic microorganisms [Akira and Takeda, 2004]. Alpha interferon (IFN- $\alpha$ ) is an important antiviral cytokine produced principally by plasmacytoid dentritic cells (pDCs), which circulate in the blood at low frequency and even lower in chronic hepatitis C [Kanto et al., 2004], through the stimulation of TLR7 and TLR9 [Hornung et al., 2005; Ito et al., 2005]. TLR7 senses unmethylated viral ssRNA [Diebold et al., 2004; Heil et al., 2004]. The expression of TLR7 in humans is mainly confined to the endosome-lysosome membrane of pDCs (including hepatic pDCs), hepatic natural killer cells [Seki and Brenner, 2008], and B lymphocytes [Hornung et al., 2002]. When the virus or virusinfected apoptotic cells are taken up by phagocytes, viral RNA is released in the highly acidified phagolysosome by degradation enzymes, leading to ssRNA release and recognition by TLR7. Upon TLR7 stimulation, a complex cascade is formed, starting with myeloid differentiation factor 88 (MyD88) and ending with the production of IFN- $\alpha /$ IFN-inducible genes and proinflammatory cytokines through the phosphorylation of interferon regulatory factor 7 and the liberation of nuclear factor- $\kappa \mathrm{B}$, respectively (reviewed in [Akira et al., 2006; Schwabe et al., 2006; Seki and Brenner, 2008]).

Macrophages overexpressing HCV nonstructural proteins NS3, NS3/4A, NS4B, or NS5A show a strong suppression of TLR-MyD88-dependent signaling pathway. NS5A interacts with MyD88 to prevent cytokine production, such as interleukin-1 (IL-1), IL-6, and beta interferon (IFN- $\beta$ ) in response to TLR7 ligands [Abe et al., 2007]. In addition, pDCs from HCV patients have reduced deviation marker (HLA-DR) and IFN- $\alpha$ expression in response to 
TLR7 ligand, which is associated with an impaired activation of naive CD4 T cells [Yonkers et al., 2007]. TLR7 has been recently of particular medicinal chemistry interest because its small molecule ligands may serve as immune stimulants by enhancing endogenous IFN- $\alpha$ production and thus, they may complement IFN- $\alpha$ therapy of chronic HCV infection, especially in IFN- $\alpha$-resistant patients. Horsmans and colleagues have applied a well-tolerated intravenous isatoribine treatment with only few mild to moderate adverse events for one week to chronic hepatitis $\mathrm{C}$ patients. It has resulted in viral load reduction regardless of the patients' HCV genotype, an induction of the antiviral immunity marker 2'-, 5'- oligoadenylate synthetase, and an increase in the levels of the gamma interferon (IFN- $\gamma$ )-inducible protein 10 (IP-10) and neopterin, a marker of macrophage activation [Horsmans et al., 2005]. Moreover, a high-affinity ligand of TLR7, namely SM360320, has been found to inhibit HCV replication both through type I IFN production by leukocytes, and direct activation of antiviral mechanisms in infected hepatocytes [Lee et al., 2006].

TLR7 gene is located on the X-chromosome and contains three exons [Du et al., 2000]. Recently, the leucine (Leu) variant encoded by the $\mathrm{T}$ allele of the nonsynonymous single nucleotide polymorphism (SNP) rs179008, which is located within TLR7 exon 3 and leads to the replacement of the wild allele A-encoded glutamine (Gln) at codon 11 in the protein (Gln11Leu), has been correlated with higher susceptibility to HCV infection and less chances of response to an IFN- $\alpha$-based therapy in chronic HCV-infected females [Schott et al., 2008]. Moreover, this variant has been associated with higher viral loads, accelerated progression to advanced immune suppression in human immune deficiency virus (HIV) infection, increased susceptibility to HIV-1 in women, and decreased IFN- $\alpha$ production after stimulation of healthy peripheral blood mononuclear cells (PBMCs) with the TLR7 ligand Imiquimod [Oh et al., 2009].

8 Taking the $\mathrm{X}$-linked location into account, the present study aimed to investigate the correlation between TLR7 rs179008 genotype and disease parameters in chronic hepatitis C, 
$1 \quad 100$ including the natural outcome of infection, i.e. chronic versus self-limited course, 3

\section{1 histological features, and the initial virological response to an IFN- $\alpha$ - based treatment on the} 102 one hand, and hepatic expression of innate immunity genes on the other hand. 


\section{PATIENTS AND METHODS}

104

105 Patients

106 From a total of 144 mainly Caucasian chronic hepatitis C patients who consulted the Liver

107 Unit of the Department of Gastroenterology and Endocrinology at the University Medical

108 Center Goettingen (UMG), Germany, between 1993 and 2006, 136 with complete data sets

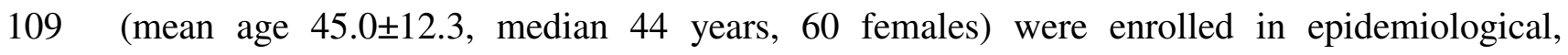

110 biochemical and histological analyses. Chronic infection was proven by detection of HCV-

111 specific antibodies and HCV RNA in the patients' sera using a highly sensitive nested RT-

112 PCR over a period of at least six months as described [Mihm et al., 1996a]. Before the start of

113 therapy, liver biopsy procedures were performed and liver disease was confirmed in the

114 course of a defined histological evaluation as described below. Biochemical liver disease

115 parameters, i.e. serum activities of aspartate aminotransferase (AST), alanine

116 aminotransferase (ALT), and gamma-glutamyl transferase $(\gamma-\mathrm{GT})$ were recorded in parallel.

117 Patients with concomitant non-C viral infections and those with continued alcohol or other 118 drug abuse were excluded.

119 A total of 55 patients (mean age $46.1 \pm 12.3$, median 45 years, 25 females) were treated with

120 IFN- $\alpha_{2 \mathrm{a}}$ (Roferon A; Hoffman-La Roche, Basel, Switzerland) at an initial dose of $6 \times 10^{6}$ IU 3x

121 per week for at least 4 months (mean, 7.7 months; range 4-12 months). Depending on well

122 being and response parameters, both dose and duration were adapted individually. Initial

123 virological response to therapy, which is defined as the elimination of HCV RNA below the

124 limit of detectability during the first 4 months for a period of a least three consecutive months,

125 was analyzed with regard to TLR7 rs179008 genotype.

126 Another group of 44 patients with self-limited HCV infection (mean age 37.0 \pm 10.3 , median

12736 years, 14 females) was studied in addition. Spontaneous elimination was assured by the 128 presence of anti-HCV antibodies in the absence of detectable amounts of HCV RNA (for 
129 detailed epidemiological and serological description of this cohort please refer to [Wietzke-

130 Braun et al., 2007]).

131 The study was approved by the local ethical committee and conformed to the ethical

132 guidelines of the 2000 Declaration of Helsinki. Patients gave their informed consent.

134 Determination of HCV Genotype

$135 \mathrm{HCV}$ genotyping was performed using the Innolipa HCV II line probe assay (Innogenetics, 136 Ghent, Belgium).

137

138 Histological Evaluation

139 Before the start of therapy, liver biopsies were taken from patients for histological evaluation.

140 In brief, sections $(5-10 \mu \mathrm{m})$ from formalin-fixed and paraffin-embedded liver biopsies were 141 stained with hematoxylin-eosin, trichrome, and Prussian blue. According to Desmet and 142 colleagues, necroinflammatory activity (grading, score 1 to 3 ) and architectural alterations 143 (staging, score 0 to 4) were scored separately [Desmet et al., 1994]. Other lesions typical of 144 hepatitis $\mathrm{C}$ such as the degree of steatosis (score 0 to 3 ), the presence or absence of portal 145 lymphoid aggregates, and the presence or absence of bile duct damage were studied 146 additionally as previously described [Mihm et al., 1997].

148 Preparation of PBMCs

149 PBMCs from approximately $30 \mathrm{ml}$ of heparinized peripheral blood samples were prepared by

150 Ficoll density centrifugation using guanidinium isothiocyanate as described [Boyum, 1984].

152 Isolation of Genomic DNA (gDNA) and Total Cellular RNA

153 gDNA was purified from PBMCs or from $2 \mathrm{ml}$ samples of serum using the QIAamp DNA

154 Mini or Midi Kits, respectively, following the blood and body fluid spin protocol (Qiagen, 
155 Hilden, Germany). The concentration and the purity of the DNA isolated from PBMCs were

156 determined photometrically by reading the absorbance levels at $260 \mathrm{~nm}$ and $280 \mathrm{~nm}$. The

157 integrity of gDNA was ascertained through electrophoresis using a $0.6 \%$ agarose gel.

158 Total cellular RNA was prepared from available freshly isolated PBMCs and homogenized

159 liver tissue samples by $\mathrm{CsCl}$ density gradient ultracentrifugation essentially as described

160 [Mihm et al., 1996b].

161

162 Reverse Transcription

163 To get complementary DNA (cDNA), an amount of $1 \mu \mathrm{g}$ of total cellular RNA was reverse

164 transcribed by using random hexamers $(6 \mu \mathrm{M})$ for priming as described previously [Mihm et 165 al., 1996b].

166

167 Genotyping for the Variant Position rs179008/GIn11Leu

168 Allelic discrimination of the TLR7 exon 3-located SNP was performed by the commercially

169 available TaqMan genotyping assay C_2259574_10 (Applied Biosystems, Foster City, CA).

170 Reactions of $10 \mu \mathrm{l}$ containing 4 ng of PBMCs-derived gDNA- or an aliquot corresponding to

$1716.7 \mu \mathrm{l}$ serum- were performed in the sequence detection system StepOne-Plus (Applied

172 Biosystems, Darmstadt, Germany) according to the supplier's instructions.

173

174 Allele-Specific Transcript Quantitation (ASTQ) of TLR7 rs179008 Variants

175 Discrimination and quantitation of TLR7 rs179008 transcript variants (A and T) was achieved

176 by applying the commercially available TaqMan genotyping assay C_2259574_10 (Applied

177 Biosystems, Foster City, CA) on cDNA samples (3.2 ng). Heterozygote gDNA and 178 homozygote gDNA and cDNA samples served as controls.

179

180 Quantification of Hepatic Gene Expression 
181 Competitive RT-PCR was applied to quantify mRNA transcripts of $\mathrm{HCV}$, the IFN- $\alpha / \beta$

182 inducible antiviral myxovirus resistance protein-1 gene (MxA), IFN- $\alpha$ and, as a reference 183 gene, albumin, essentially as described [Mihm et al., 2004], and transcripts of IP-10, the gene 184 encoding IFN- $\alpha /$-inducible p44 [Patzwahl et al., 2001], IFN- $\gamma$ [Mihm et al., 1996b]. The

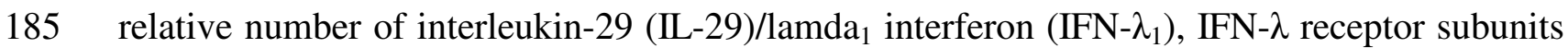
186 (IL-10Rß and IL28R $\alpha$ ), and IFN- $\alpha / \beta$ receptor 2 (IFNAR2) mRNA transcripts was calculated 187 by real-time RT-PCR using the sequence detection system ABI prism 7000 following the 188 supplier' instructions (Applied Biosystems, Darmstadt, Germany) as described [Doyle et al., 189 2006; Mihm et al., 2004]. Glycerinaldehyde-3-phosphate dehydrogenase (GAPDH) 190 transcripts served as a housekeeping gene, using a commercially available TaqMan gene 191 expression Assay on Demand (Hs 99999905 ml) (Applied Biosystems). Comparable results 192 were found when relating the targets to $ß$-actin transcripts (data not shown).

193

\section{Statistical Analysis}

195 Females and males were analyzed both separately (data shown in the text where necessary), 196 and combined due to the ASTQ results. Quantitative parameters were described by mean and 197 standard deviation if the data are normally distributed, or median and inter-quartile range 198 (IQR) if the distribution is not normal. $\chi^{2}$-test and independent samples $t$-test were applied 199 where applicable. The level of significance was set to a screening level of 0.05 . All tests were 200 performed by using PC STATISTIK software package version 4.0 (Hoffmann-Software, 201 Giessen, Germany). 


\section{RESULTS}

\section{Genotyping of HCV with Regard to TLR7 rs179008}

204 A total of 136 patients with chronic hepatitis C (60 females/76 males) were genotyped for the 205 bi-allelic SNP rs179008/GIn11Leu within exon 3 of the X-linked TLR7 gene (Table I). 206 Genotype distribution in women followed Hardy-Weinberg equilibrium $(P=0.318)$. The 207 frequency of the minor allele (MAF) was found to be close to that given for Caucasians in 208 public data bases and to be similar in females and males $(P=0.175)$.

\section{ASTQ}

211 Due to the X-linked location of TLR7, in females, the random inactivation of one $\mathrm{X}$ 212 chromosome leads to cellular mosaicism with two populations of cells differing in the 213 parental origin of the active X [Fish, 2008]. In heterozygous females, the presence of two 214 kinds of cells might set up a competition between them [Migeon, 2006]. Non-random 215 inactivation (skewing) has been implicated for discrete cell populations, e.g. dendritic cells 216 [Fish, 2008; Migeon, 2006]. In order to find out whether heterozygous females should be 217 assigned either to the wildtype, the variant genotype or to be considered as a separate, i.e. true 218 heterozygous group, ASTQ was performed to quantify the relative proportion of A and T 219 allele transcript variants in RNA preparation from freshly isolated PBMCs (Fig. 1). gDNA, a 220 natural source of equal amounts of $\mathrm{A}$ and $\mathrm{T}$ sequences served as a control. RNA preparations 221 from 3 heterozygous women were found to contain nearly equal numbers of both alleles' 222 transcripts, whereas material from 4 heterozygous females was found to contain an excess of 223 either A or T, 2 women each, respectively (Fig. 1A).

224 Because of the limited amount of available samples, 5 heterozygous females were further 225 identified among a total of 42 healthy blood donors. ASTQ with these 5 samples yielded 226 comparable results (equal expression in 2 samples, an excess of $\mathrm{A}$ in 3 samples) (data not 227 shown). 
228 On the basis of these findings we decided to restrict analyses to the comparison between A 229 and T homo- and hemizygous individuals. 230

\section{Epidemiological and Biochemical Characteristics}

232 Demographic analysis revealed a slight trend of the variant allele carriers to be older than 233 those who carry the wild type allele $(47.8 \pm 15.0$ vs. $42.5 \pm 11.2$, respectively, $P=0.069)$. This 234 difference, however, was clearer in males $(P=0.083)$ (Table I).

235 As expected for a European population, most patients (80.1\%) were infected with HCV type-1 236 (including subtypes $1 \mathrm{~b}, 1 \mathrm{a}$ and $1 \mathrm{a}+1 \mathrm{~b}$ ), while $19.9 \%$ were infected with HCV non-1 237 (including mainly subtypes $3 a$, and a minority of $2 a$ and $2 b$ ). No significant difference among 238 the distribution of HCV types (or subtypes, data not shown) infections according to patients' 239 TLR7 rs179008 genotype was found (Table I).

240 AST, ALT, and $\gamma$-GT serum activities were recorded as indicators of liver injury in chronic 241 hepatitis C. Although T homo- and hemizygotes seemed to have higher AST and ALT but 242 lower $\gamma$-GT serum levels than the A counterparts, the proportion of A or T homo- and 243 hemizygote patients among those with markedly elevated transaminase activities, i.e. greater 244 than 2-fold of the upper normal limit, was not found to be significantly different (Table I).

\section{Genotyping of Individuals with Self-limited HCV Infection}

247 The T allele is suggested to confer enhanced susceptibility to chronic HCV infection as MAF 248 has been found to be significantly lower in healthy individuals [Schott et al., 2008]. To 249 address the question whether this enhanced susceptibility is due to a higher incidence of 250 infection or to an impaired capacity to self-eliminate the virus, TLR7 rs179008 genotype 251 distribution of the chronic hepatitis $\mathrm{C}$ patients was compared to a group of 44 patients with 252 self-limited HCV infection [Wietzke-Braun et al., 2007]. The proportion of T homo- and 253 hemizygous individuals or even of heterozygous female patients was not found to be 
254 significantly higher in chronic $\mathrm{HCV}$ patients $(15.4 \%$ and $14.7 \%$, respectively) in 255 comparison to patients with self-limited $\mathrm{HCV}$ infection (11.4\% and $13.6 \%$, respectively) 256 (Table I).

257

258 Hepatitis C Histological Manifestations

259 To investigate whether a functionally impaired TLR7 protein might be related to histological 260 features of chronic hepatitis C, liver biopsy specimens were taken and evaluated histologically 261 with regard to hepatitis activity, fibrosis progression, steatosis stage, portal lymphoid 262 aggregates and bile duct damage (Table II). TLR7 rs179008 genotype distribution showed no 263 association with the first three characteristics. Nevertheless, a higher frequency of the minor 264 allele $\mathrm{T}$ among patients with portal lymphoid aggregates was observed $(P=0.013)$, this 265 difference, however, was only valid in males $(P=0.032)$ (Table II). Whereas only $30.5 \%$ of A 266 carriers were found to have bile duct damage, 52.4\% of $\mathrm{T}$ carriers did have the lesion $(P=$ 267 0.051) (Table II).

268 Noteworthy, it was reported recently that patients homozygous for the variant allele $\mathrm{T}$ of the 269 endotoxin receptor CD14 SNP rs2569190/C-159T have more frequent portal lymphoid 270 aggregates than C carriers [Askar et al., 2009]. Interestingly, analyzing CD14 C-159T 271 genotype separately in the two genders revealed that the significant association was only 272 confined to males $(P=0.004)$ (unpublished observation).

273

274 Response to an IFN- $\alpha_{2 a}$ Monotherapy

275 A total of 55 patients were treated with IFN- $\alpha 2$ a as described in the patients and methods 276 section. The initial virological response to therapy is defined as the elimination of HCV-RNA 277 below the limit of detectability during the first 4 months for a period of at least 3 consecutive 278 months. Some patients kept undetectable viral RNA levels till completing therapy i.e. end-of279 treatment response, or even for a period of at least continuous six months after the last dose of 
280 IFN- $\alpha_{2 a}$, i.e. sustained virological response. While $22(63 \%)$ of the A carriers responded, at 281 least initially, to the therapy, only $3(30 \%)$ of the T counterparts (and 30\% of the heterozygous 282 females) were responders $(P=0.069)$ (Table III). Similar results were found considering a 283 larger cohort of 145 patients treated with an IFN- $\alpha$-based therapy (data not shown). 284

285 Hepatic Gene Expression

286 To examine whether a functionally impaired TLR7 protein might be related to hepatic gene 287 expression in chronic $\mathrm{HCV}$ infection, innate immunity gene transcripts were quantified in 288 freshly derived liver tissue samples. Data were related both to GAPDH and to albumin as 289 reference genes. When A homo- and hemizygous samples were compared to T homo- and 290 hemizygous samples, no significant difference was found with regard to the amount of hepatic 291 viral RNA (Fig. 2A), or the genes that have been shown to be enhanced in chronic HCV 292 infection when compared to healthy liver tissue as IP-10, p44, MxA, or IFN- $\gamma$ [Mihm et al., 293 2004] (Fig. 2B). In contrast, T homo- and hemizygotes were found to express significant 294 lower amounts of IL-29/IFN- $\lambda_{1}(P=0.015)$, IL-10 receptor beta (IL-10Rß) $(P=0.001)$ and 295 IL-28 receptor alpha $(\mathrm{IL}-28 \mathrm{R} \alpha)(P=0.003)$, which constitute the two components of IFN- $\lambda$ 296 heterodimeric receptor, as well as lower amounts of IFN- $\alpha$ and $\operatorname{IFNAR}_{2}$ (Fig. 2B). 


\section{DISCUSSION}

298 The TLR7 rs179008/Gln11Leu is located in the signal sequence of TLR7, adjacent to the 299 typical basic residues in the N-terminal part of this sequence. Signal peptide degeneracy 300 modulates posttranslational modification, localization, quantity and thus the functionality of 301 the affected protein [Hegde and Bernstein, 2006]. In the studied cohort of 136 chronic 302 hepatitis C patients, no significant association was found between TLR7 rs179008 and any of 303 the epidemiological or biochemical characteristics, inflammation activity (grading) or fibrosis 304 progression (staging). These results are in concordance with previous findings [Schott et al., 305 2007]. Considering the presence of portal lymphoid aggregates, a significant higher frequency 306 of the $\mathrm{T}$ hemizygosity was found among male patients. Portal lymphoid aggregates are 307 defined as densely packed collection of small lymphocytes within the portal tract with or 308 without the formation of a germinal center [Luo et al., 1999]. Their presence, which is 309 suggested to play an immunological albeit indeterminate role in chronic HCV liver injury 310 similar to the mechanism of autoimmune hepatitis [Hino et al., 1992; Mosnier et al., 1993], 311 has been found to be significantly correlated with hepatic inflammatory activity and bile duct 312 damage [Askar et al., 2009; Freni et al., 1995; Luo et al., 1999; Wong et al., 1996]. 313 Interestingly, the common allele A trended to be low-frequented among patients with bile duct 314 damage $(P=0.051)$ (Table II).

315 Portal lymphoid aggregates have been recently found to be more frequent among patients 316 homozygote for the T allele of CD14 rs2569190/C-159T [Askar et al., 2009], this association, 317 however, was valid only in males as it is for TLR7 rs179008 in the present study. Noteworthy, 318 sex itself is neither found to be associated with portal lymphoid aggregates [Askar et al., 319 2009; Luo et al., 1999; Mihm et al., 1997], nor with CD14 rs2569190 genotype distribution 320 [Askar et al., 2009]. Freni et al. described the cellular composition of this manifestation as a 321 core of B cells -which do express TLR7- mixed with many T helper/inducer lymphocytes, and 322 an outer ring prominently formed by $\mathrm{T}$ suppressor/cytotoxic lymphocytes, and a rarely 
323 identifiable germinal center [Freni et al., 1995]. Taken together, being the first observation 324 of its kind, although its real biological mechanism is still to be found out, replication in an 325 independent larger cohort, and correction of multiple testing are required, TLR7 rs179008 326 might have a role in the formation of portal lymphoid aggregates.

327 TLR7 rs179008 T allele has been found recently to be over-represented and predictive of 328 unfavourable outcome of IFN- $\alpha$ therapy in female patients with chronic HCV infection 329 [Schott et al., 2008]. In the present study, we investigated the distribution of this SNP among 330 patients who spontaneously resolved HCV infection. Comparing the two cohorts with regard 331 to TLR7 rs179008 genotype did not reveal any significant difference (Table I). Unfortunately, 332 this analysis lacks statistical power due to the small cohort of self-limited individuals, yet it 333 did not give any preliminary indication for an altered capacity of resolving the infection 334 spontaneously. Moreover, the observed slight (but still non-significant) trend of the TT/T 335 patients to be non-responders to a mono- or a combined IFN- $\alpha$ - based therapy and to have 336 lower hepatic expression of both IFN- $\alpha$ and IFNAR $_{2}$ might confirm - in general - the previous 337 findings of Schott et al [2007] with cautious limitations due to the novel ASTQ analyses in 338 this study that let us omit female heterozygotes from our analyses.

339 The impaired receptor appeared not to affect HCV hepatic viral load, accordingly, no further 340 effect was observed on $\mathrm{p} 44, \mathrm{MxA}, \mathrm{IFN}-\gamma$ or IP-10, genes known to be upregulated in chronic 341 HCV infection in the absence of hepatic type I IFN induction [Mihm et al., 2004]. The minor 342 allele $\mathrm{T}$, however, was found to be significantly associated with lower hepatic mRNA 343 expression of IL-29/IFN- $\lambda_{1}$ and both IL-10R $\beta$ and IL-28R $\alpha$ (Fig. 2B). This suggests that, 344 rather than being useful in forecasting the current IFN- $\alpha$ - based therapy outcomes, genotyping 345 for TLR7 rs179008 might be predictive for response to IL-29/IFN- $\lambda_{1}$ based therapy 346 approaches [Sheppard et al., 2003] currently being in phase 2 of clinical development.

347 Three independent genome-wide association studies (GWASs) have reported recently 348 onseveral SNPs in the intergenic region between the genes coding for IL-28A/IFN- $\lambda_{2}$ and IL- 
$34928 \mathrm{~B} / \mathrm{IFN}-\lambda_{3}$ on chromosome 19 to be associated with response outcomes to an IFN- $\alpha$ 350 based therapy [Ge et al., 2009; Suppiah et al., 2009; Tanaka et al., 2009] and with 351 spontaneous clearance of HCV [Thomas et al., 2009]. The minor non-responder allele of 352 rs8099917 in IL-28B/IFN- $\lambda_{3}$ gene has been found, moreover, to be associated with lower IL35328 mRNA expression in PBMCs [Suppiah et al., 2009; Tanaka et al., 2009]. These GWASs 354 have identified as well many SNPs in several genes to be of minor predictability for IFN- $\alpha$ 355 based therapy outcomes, TLR7, however, not to be among them.

356 Taken together, despite of significant decreased hepatic gene expression in TLR7 rs179008 T 357 compared to A allele patients, that might be due to improper virus sensing and that might 358 affect responsiveness to IL-29/IFN- $\lambda_{1}$ rather than IFN- $\alpha$, differences in phenotype of disease 359 including hepatic viral load, natural outcome of infection, and disease activity and progression 360 appear to be minor with the exception of the presence of portal lymphoid aggregates in $\mathrm{T}$ 361 hemizygous males. Further investigations will elucidate the impact of this polymorphism on 362 responsiveness to endogenous and probably exogenous IFN- $\lambda$. 


\section{ACKNOWLEDGMENTS}

364

365 The authors thank all physicians of the Department of Gastroenterology and Endocrinology,

366 UMG, who were involved in patients' care and control for their kind cooperation, PD Dr.

367 Stefan Schweyer, Department of Pathology, UMG, for his help in histological evaluation of 368 patients' liver biopsies, and Waltraut Kopp for expert technical assistance. The authors also 369 thank Prof. em. Dr. Gerhard Hunsmann, German Primate Center and the Institute of Virology, 370 Goettingen, Germany, for his interest, supervision and many helpful discussions. E.A. is 371 thankful for her scholarship from Damascus University, Syria. This project was supported by 372 a grant of the Deutsche Forschungsgemeinschaft MI 474/1-1. 


\section{TLR7 ASTQ in Heterozygous Female Hepatitis C Patients}

376

377

378

392 393

(A) ASTQ carried out on corresponding gDNA and cDNA samples from 3 representative TLR7 rs179008 heterozygous female patients revealed either nearly equal amounts of both alleles (top), a 2.7-fold excess of the A allele variant (middle), or a 2.6-fold excess of the T allele variant (bottom). Analyses were made in duplicate, therefore the mean $\Delta \mathrm{CT}$ is given but one representative amplification plot is shown.

(B) ASTQ carried out on one representative pair of corresponding gDNA and cDNA samples from a TLR7 rs179008 homozygote T patient yielded only non-specific signal for the allele A as defined by a 10-fold less fluorescence intensity in the plateau phase at the end of the reaction.

\section{LEGEND TO FIGURE 2:}

\section{Hepatic Gene Expression in Chronic Hepatitis C Patients with Regard to TLR7} rs179008 Genotype

Total cellular RNA from liver biopsy specimens taken from homo- and hemizygous patients with chronic hepatitis C was quantified with respect to (A) HCV RNA, (B) p44, MxA, IP-10, IFN- $\gamma$ and IFN- $\alpha$ in relation to albumin mRNA transcripts by using competitive quantitative RT-PCR, and IL-10Rß, IL-28R $\alpha$, IL-29 and IFNAR 2 in relation to GAPDH mRNA by using quantitative real-time RT-PCR assays. Data are given as ratios of the target to reference gene $\mathrm{x} 10^{-3}$. Medians are indicated by horizontal bars. Levels of significance are given. Similar results were obtained when data were related to $\beta$-actin (data not shown). 
1

2

3

4

5

6

7

8

9

10

11

12

13

14

15

16

17

18

19

20

21

22

23

24

25

26

27

28

29

30

31

32

33

34

35

36

37

38

39

40

41

42

43

44

45

46

47

48

49

50

51

52

53

54

55

56

57

58

59

60
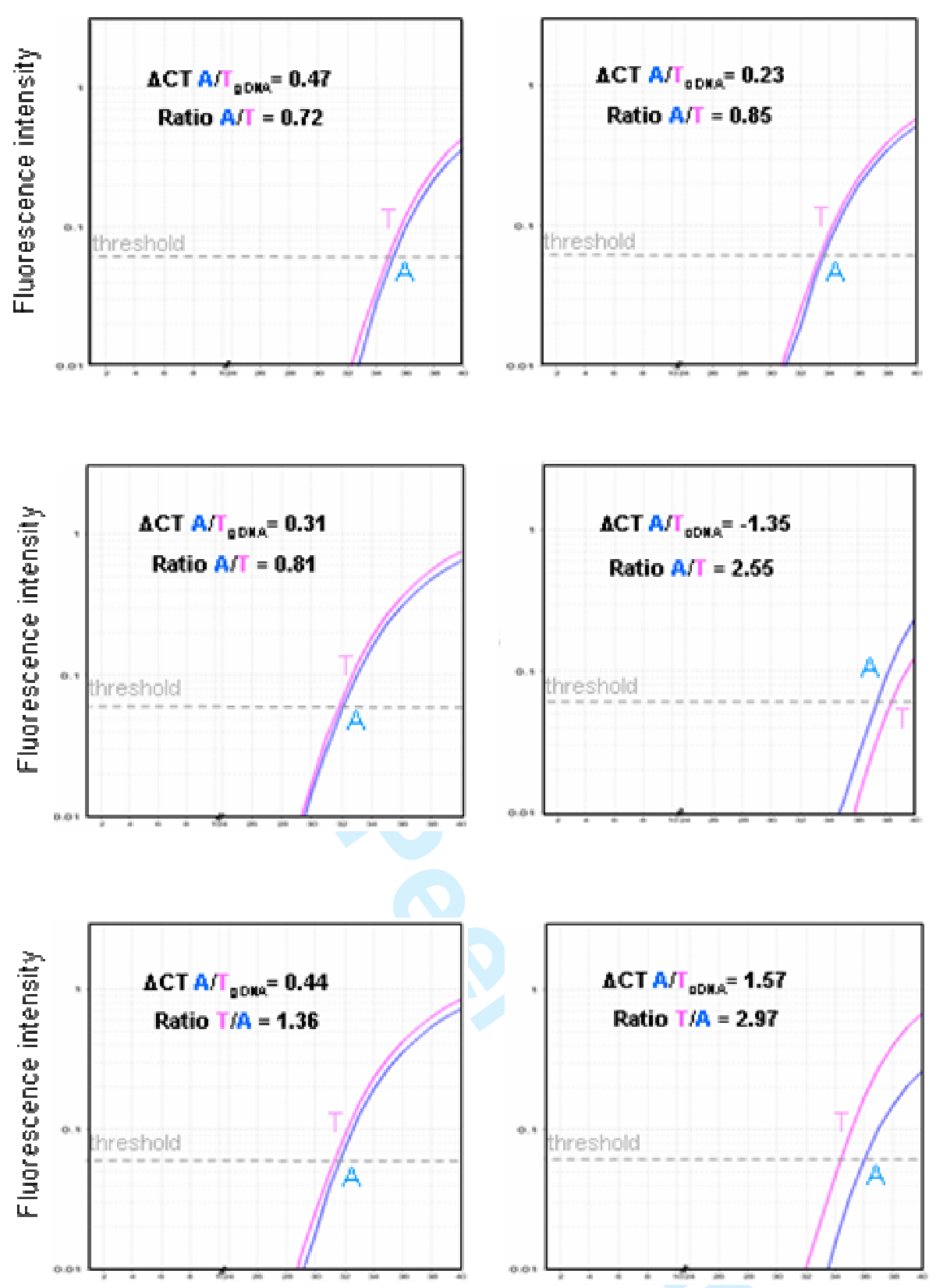

399

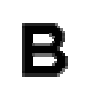

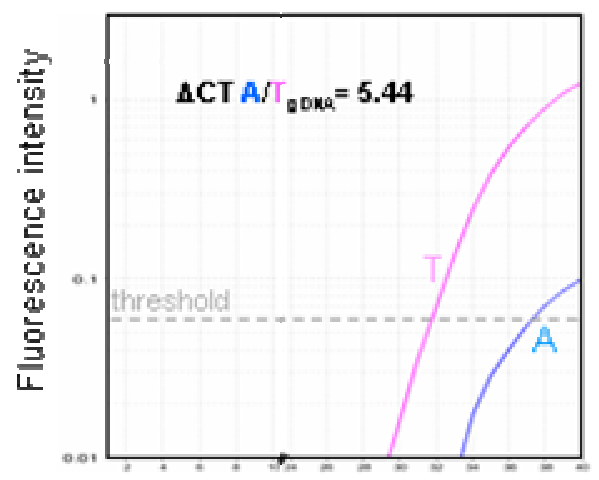

Number of cycles

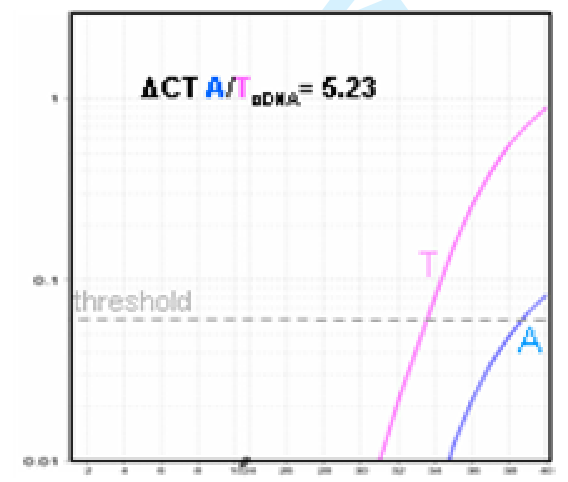

Number of cycles 
401
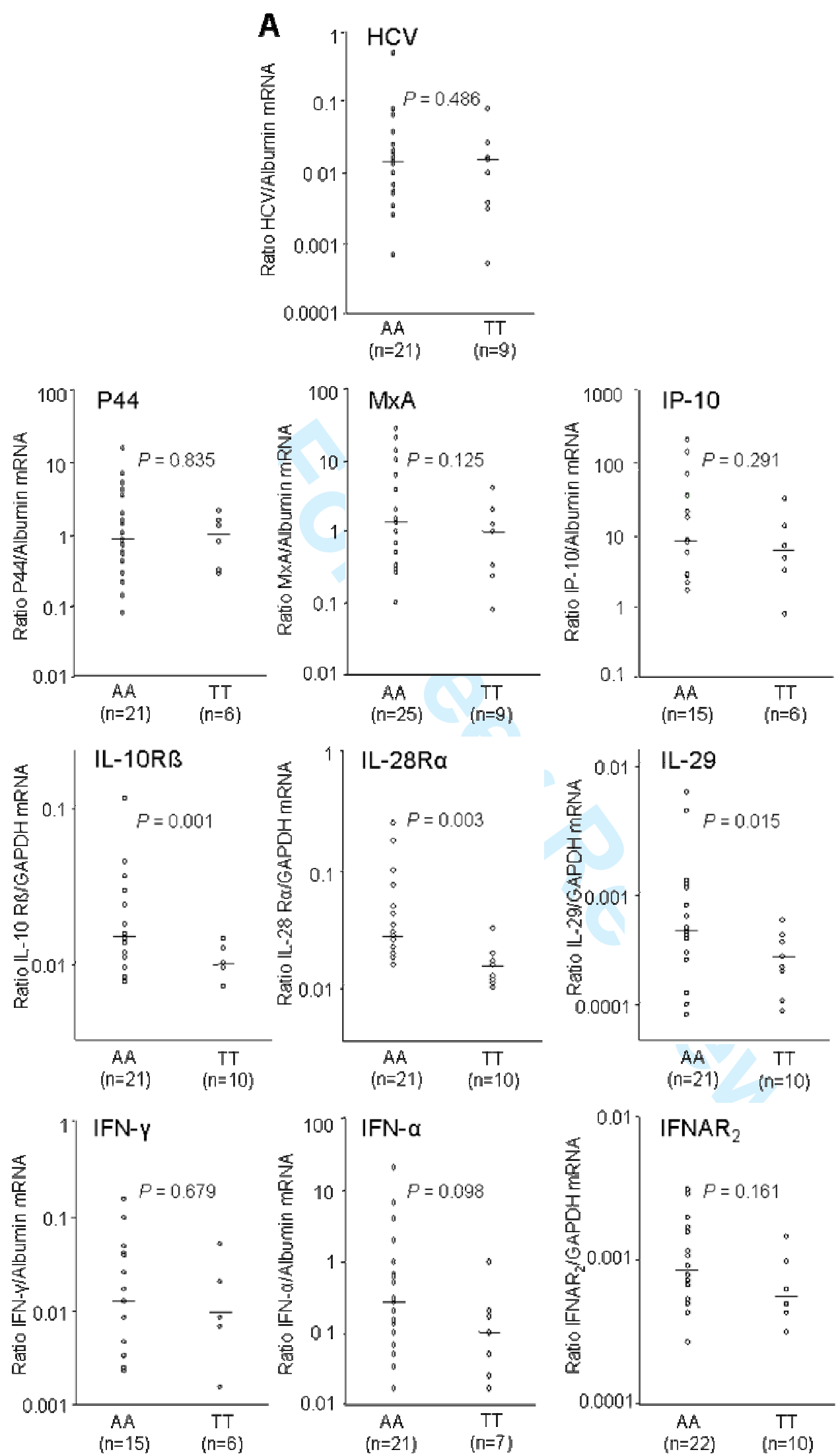

402
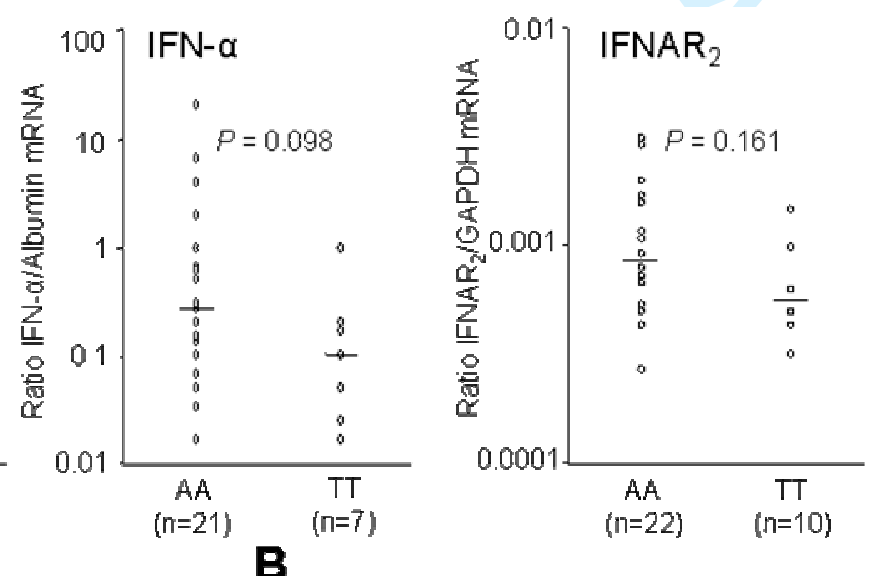
Table I. TLR7 rs179008 Genotype Distribution in Patients with Chronic or Self-limited HCV Infection with Regard to Epidemiological and Biochemical Parameters

\begin{tabular}{|c|c|c|c|c|c|c|c|c|}
\hline & \multirow[b]{3}{*}{$n$} & \multicolumn{6}{|c|}{ TLR7 rs179008 genotype } & \multirow{3}{*}{ MAF } \\
\hline & & \multicolumn{2}{|r|}{ Females } & \multicolumn{4}{|c|}{ Males } & \\
\hline & & AA & AT & TT & A & $\mathbf{T}$ & $\boldsymbol{P}$ & \\
\hline \multicolumn{9}{|l|}{ Patients with chronic HCV infection } \\
\hline Number $(\%)$ & 136 & $34(56.7)$ & $20(33.3)$ & $6(10.0)$ & $61(80.3)$ & $15(19.7)$ & $0.175^{\mathrm{b}}$ & $0.267 / 0.197^{a}$ \\
\hline Age (Mean $\pm S D)$ & & $45.8 \pm 10.7$ & $46.6 \pm 11.5$ & $50.0 \pm 13.6$ & $40.7 \pm 11.2$ & $46.9 \pm 15.9$ & $0.069^{c}$ & \\
\hline $\begin{array}{l}\text { HCV types } \\
\text { HCV type-1 n (\%) } \\
\text { HCV non-1 n (\%) }\end{array}$ & $\begin{array}{c}109 \\
27\end{array}$ & $\begin{array}{r}28(53.9) \\
6(75.0)\end{array}$ & $\begin{array}{r}19(36.5) \\
2(25.0)\end{array}$ & $\begin{array}{l}5(9.6) \\
0(0)\end{array}$ & $\begin{array}{l}47(82.5) \\
14(73.7)\end{array}$ & $\begin{array}{l}10(17.5) \\
5(26.3)\end{array}$ & $0.449^{d}$ & $\begin{array}{l}0.279 / 0.175^{\mathrm{a}} \\
0.143 / 0.263^{\mathrm{a}}\end{array}$ \\
\hline \multicolumn{9}{|l|}{ Biochemical Serum Parameters } \\
\hline $\begin{array}{l}\text { AST (Median, IQR) } \\
\text { Patients with elevated/normal AST }\end{array}$ & & $23.0,15-38$ & $18.5,13.5-31.5$ & $45,16-80$ & $29,18-67$ & $36,18-52$ & & \\
\hline No. Patients with elevated/normal AST & 136 & $12 / 22$ & $6 / 14$ & $3 / 3$ & $28 / 33$ & $7 / 8$ & $0.411^{d}$ & \\
\hline $\begin{array}{l}\quad A L T \text { (Median, IQR) } \\
\text { No. Patients with elevated/normal ALT }\end{array}$ & 136 & $\begin{array}{l}32.5,22-60 \\
13 / 21\end{array}$ & $\begin{array}{c}31.5,20.5-44 \\
7 / 13\end{array}$ & $\begin{array}{c}58,22.90 \\
3 / 3\end{array}$ & $\begin{array}{c}58,36.5-129 \\
36 / 25\end{array}$ & $\begin{array}{l}78,47-92 \\
12 / 3\end{array}$ & $0.078^{d}$ & \\
\hline $\begin{array}{l}\text { Y-GT (Median, IQR) } \\
\text { No. Patients with elevated/normal } Y-G T^{e}\end{array}$ & 136 & $\begin{array}{l}19.5,10-45 \\
10 / 24\end{array}$ & $\begin{array}{c}19.5,13.5-41 \\
5 / 15\end{array}$ & $\begin{array}{l}17,5-34 \\
2 / 4\end{array}$ & $\begin{array}{l}39,23.5-62.5 \\
17 / 44\end{array}$ & $\begin{array}{c}24,14-72 \\
5 / 10\end{array}$ & $0.419^{d}$ & \\
\hline $\begin{array}{l}\text { Patients with self-limited HCV infection } \\
\text { Number }(\%) \\
\text { Age (Mean } \pm S D)\end{array}$ & 44 & $\begin{array}{c}7(50.0) \\
39.3 \pm 10.4\end{array}$ & $\begin{array}{c}6(42.9) \\
38.0 \pm 13.2\end{array}$ & $\begin{array}{c}1(7.1) \\
30\end{array}$ & $\begin{array}{c}26(86.7) \\
36.0 \pm 9.9\end{array}$ & $\begin{array}{r}4(13.3) \\
40.5 \pm 9.7 \\
\end{array}$ & $\begin{array}{l}0.766^{\dagger} \\
0.722^{g}\end{array}$ & $0.286 / 0.133^{\mathrm{a}}$ \\
\hline
\end{tabular}

${ }^{\mathrm{a}} \mathrm{MAF}$ is given for females/males, respectively, ${ }^{\mathrm{b}} \chi^{2}$-test was applied to compare MAF between females and males. ${ }^{\mathrm{C}}$ Independent samples $t$-test was applied, the trend was valid only in males $(P=0.083),{ }^{d} \chi^{2}$-test was applied to compare A with $\mathrm{T}$ homo- and hemizygous patients (combined females males).

${ }^{e}$ Markedly elevated serum activities of transaminases (>2-fold of the upper normal limit) were considered. Upper normal limits for females/males, respectively are: $15 \mathrm{U} / \mathrm{L} / 19 \mathrm{U} / \mathrm{L}$ for AST, $19 \mathrm{U} / \mathrm{L} / 23 \mathrm{U} / \mathrm{L}$ for ALT; and $18 \mathrm{U} / \mathrm{L} / 28 \mathrm{U} / \mathrm{L}$ for $\gamma$-GT.

${ }^{f} \chi^{2}$ - test was applied to compare TLR7 rs179008 genotype distribution in patients with chronic- and patients with self-limited HCV infection.

${ }^{9}$ Independent samples $t$-test was applied. 
Table II. Histological Manifestations of Chronic Hepatitis C Patients with Regard to TLR7 rs179008 Genotype

\begin{tabular}{|c|c|c|c|c|c|c|}
\hline \multirow{3}{*}{ Histological manifestations } & \multicolumn{6}{|c|}{ TLR7 rs179008 genotype } \\
\hline & \multicolumn{3}{|c|}{ Females n (\%) } & \multicolumn{2}{|c|}{ Males n (\%) } & \multirow[b]{2}{*}{$P^{a}$} \\
\hline & AA & AT & TT & A & $\mathbf{T}$ & \\
\hline & \multicolumn{3}{|c|}{ Hepatitis activity } & & & \multirow{4}{*}{0.156} \\
\hline Mild & $20(57.1)$ & $12(34.3)$ & $3(8.6)$ & $35(85.4)$ & $6(14.6)$ & \\
\hline Moderate & $13(59.1)$ & $6(27.3)$ & $3(13.6)$ & $22(75.9)$ & $7(24.1)$ & \\
\hline \multirow{2}{*}{ Severe } & 1 (33.3) & $2(66.7)$ & $0(0)$ & $4(66.7)$ & $2(33.3)$ & \\
\hline & Fibrosis & & & & & \multirow{6}{*}{0.222} \\
\hline Absent & $5(55.7)$ & $3(33.3)$ & $1(11.1)$ & $9(100.0)$ & $0 \quad(0)$ & \\
\hline Mild & $18(56.3)$ & $11(34.4)$ & $3(9.4)$ & $29(80.6)$ & $7(19.4)$ & \\
\hline Modorate & $6(54.6)$ & $4(36.4)$ & $1(9.1)$ & $11(37.3)$ & $4(26.7)$ & \\
\hline Marked & $4(66.7)$ & $1(16.7)$ & $1(16.7)$ & $5(62.5)$ & $3(37.5)$ & \\
\hline \multirow[t]{2}{*}{ Cirrhosis } & $1(50.0)$ & $1(50.0)$ & $0(0)$ & $7(87.5)$ & $1(12.5)$ & \\
\hline & Steatosi & & & & & \multirow{5}{*}{0.509} \\
\hline Absent & $15(60.0)$ & $7(28.0)$ & $3(12.0)$ & $27(77.1)$ & $8(22.9)$ & \\
\hline Mild & $12(50.0)$ & $10(41.7)$ & $2(8.3)$ & $20(83.3)$ & $4(16.7)$ & \\
\hline Moderate & $3(42.9)$ & $3(42.9)$ & $1(14.3)$ & $9(75.0)$ & $3(25.0)$ & \\
\hline \multirow[t]{2}{*}{ Marked } & $4(100.0)$ & $0 \quad(0)$ & $0(0)$ & $5(100.0)$ & $0(0)$ & \\
\hline & Portal ly & phoid ags & gates & & & \multirow{3}{*}{$0.013^{b}$} \\
\hline Absent & $25(64.1)$ & $11(28.2)$ & $3(7.7)$ & $39(88.6)$ & $5(11.4)$ & \\
\hline \multirow[t]{2}{*}{ Present } & $9(42.9)$ & 9 (42.9) & $3(14.3)$ & $22(68.8)$ & $10(31.3)$ & \\
\hline & Bile duc & damage & & & & \\
\hline Absent & $26(63.4)$ & $12(29.3)$ & $3(7.3)$ & $40(85.1)$ & $7(14.9)$ & \multirow[b]{2}{*}{0.051} \\
\hline Present & $8(42.1)$ & $8(42.1)$ & $3(15.8)$ & $21(72.4)$ & $8(27.6)$ & \\
\hline
\end{tabular}

${ }^{a} \chi^{2}$-test was applied on A and T homo- and hemizygous patients, to compare mild vs. moderate and severe hepatitis activity, absent, mild vs. moderate and marked fibrosis and cirrhosis, and absent, mild vs. moderate and marked steatosis.

${ }^{\mathrm{b}}$ The difference is valid only in males $(P=0.032)$. 
2

5

6

7

8

9

10

11

Table III. Initial Virological Response to an IFN- $\alpha_{2 a}$ Monotherapy in Chronic Hepatitis C Patients with Regard to TLR7 rs179008 Genotype

\begin{tabular}{lcccccc}
\hline & \multicolumn{5}{c}{ TLR7 rs179008 genotype } \\
\cline { 2 - 7 } & \multicolumn{7}{c}{ Females } & \multicolumn{4}{c}{ Males } \\
\cline { 2 - 7 } & AT & TT & A & T & $\boldsymbol{P}$ \\
\hline No. Non-responsive patients (\%) & $6(35.3)$ & $7(41.2)$ & $4(23.5)$ & $7(70.0)$ & $3(30.0)$ & \\
No. Responsive patients (\%) & $4(50.0)$ & $3(37.5)$ & $1(12.5)$ & $18(90.0)$ & $2(10.0)$ & $0.069^{\mathrm{a}}$ \\
\hline
\end{tabular}

${ }^{\mathrm{a}} \chi^{2}$-test was applied to compare A with T homo- and hemizygous patients. 


\section{REFERENCES}

Abe T, Kaname Y, Hamamoto I, Tsuda Y, Wen X, Taguwa S, Moriishi K, Takeuchi O, Kawai T, Kanto T, Hayashi N, Akira S, Matsuura Y. 2007. Hepatitis C virus nonstructural protein 5A modulates the toll-like receptor-MyD88-dependent signaling pathway in macrophage cell lines. J Virol 81(17):8953-8966.

Akira S, Takeda K. 2004. Toll-like receptor signalling. Nat Rev Immunol 4(7):499-511.

Akira S, Uematsu S, Takeuchi O. 2006. Pathogen recognition and innate immunity. Cell 124(4):783-801.

Askar E, Ramadori G, Mihm S. 2009. Endotoxin receptor CD14 gene variants and histological features in chronic hepatitis C virus infection. World J Gastroenterology 15(31):3884-3890.

Boyum A. 1984. Separation of lymphocytes, granulocytes, and monocytes from human blood using iodinated density gradient media. Methods Enzymol 108:88-102.

Choo QL, Kuo G, Weiner AJ, Overby LR, Bradley DW, Houghton M. 1989. Isolation of a cDNA clone derived from a blood-borne non-A, non-B viral hepatitis genome. Science 244(4902):359-362.

Desmet VJ, Gerber M, Hoofnagle JH, Manns M, Scheuer PJ. 1994. Classification of chronic hepatitis: diagnosis, grading and staging. Hepatology 19(6):1513-1520.

Diebold SS, Kaisho T, Hemmi H, Akira S, Reis e Sousa C. 2004. Innate antiviral responses by means of TLR7-mediated recognition of single-stranded RNA. Science 303(5663):1529-1531.

Doyle SE, Schreckhise H, Khuu-Duong K, Henderson K, Rosler R, Storey H, Yao L, Liu H, Barahmand-pour F, Sivakumar P, Chan C, Birks C, Foster D, Clegg CH, WietzkeBraun P, Mihm S, Klucher KM. 2006. Interleukin-29 uses a type 1 interferon-like program to promote antiviral responses in human hepatocytes. Hepatology 44(4):896906. 
Du X, Poltorak A, Wei Y, Beutler B. 2000. Three novel mammalian toll-like receptors: gene structure, expression, and evolution. Eur Cytokine Netw 11(3):362-371.

Fish EN. 2008. The X-files in immunity: sex-based differences predispose immune responses. Nat Rev Immunol 8(9):737-744.

Freni MA, Artuso D, Gerken G, Spanti C, Marafioti T, Alessi N, Spadaro A, Ajello A, Ferrau O. 1995. Focal lymphocytic aggregates in chronic hepatitis C: occurrence, immunohistochemical characterization, and relation to markers of autoimmunity. Hepatology 22(2):389-394.

Ge D, Fellay J, Thompson AJ, Simon JS, Shianna KV, Urban TJ, Heinzen EL, Qiu P, Bertelsen AH, Muir AJ, Sulkowski M, McHutchison JG, Goldstein DB. 2009. Genetic variation in IL28B predicts hepatitis C treatment-induced viral clearance. Nature 461(7262):399-401.

Hegde RS, Bernstein HD. 2006. The surprising complexity of signal sequences. Trends Biochem Sci 31(10):563-571.

Heil F, Hemmi H, Hochrein H, Ampenberger F, Kirschning C, Akira S, Lipford G, Wagner H, Bauer S. 2004. Species-specific recognition of single-stranded RNA via toll-like receptor 7 and 8. Science 303(5663):1526-1529.

Hino K, Okuda M, Konishi T, Yamashita A, Kayano K, Kubota M, Yasunaga M, Fukumoto Y, Okita K. 1992. Analysis of lymphoid follicles in liver of patients with chronic hepatitis C. Liver 12(6):387-391.

Hornung V, Rothenfusser S, Britsch S, Krug A, Jahrsdorfer B, Giese T, Endres S, Hartmann G. 2002. Quantitative expression of toll-like receptor 1-10 mRNA in cellular subsets of human peripheral blood mononuclear cells and sensitivity to $\mathrm{CpG}$ oligodeoxynucleotides. J Immunol 168(9):4531-4537. 
Horsmans Y, Berg T, Desager JP, Mueller T, Schott E, Fletcher SP, Steffy KR, Bauman LA, Kerr BM, Averett DR. 2005. Isatoribine, an agonist of TLR7, reduces plasma virus concentration in chronic hepatitis C infection. Hepatology 42(3):724-731.

Kanto T, Inoue M, Miyatake H, Sato A, Sakakibara M, Yakushijin T, Oki C, Itose I, Hiramatsu N, Takehara T, Kasahara A, Hayashi N. 2004. Reduced numbers and impaired ability of myeloid and plasmacytoid dendritic cells to polarize T helper cells in chronic hepatitis C virus infection. J Infect Dis 190(11):1919-1926.

Lee J, Wu CC, Lee KJ, Chuang TH, Katakura K, Liu YT, Chan M, Tawatao R, Chung M, Shen C, Cottam HB, Lai MM, Raz E, Carson DA. 2006. Activation of anti-hepatitis C virus responses via Toll-like receptor 7. Proc Natl Acad Sci U S A 103(6):1828-1833.

Luo JC, Hwang SJ, Lai CR, Lu CL, Li CP, Tsay SH, Wu JC, Chang FY, Lee SD. 1999. Clinical significance of portal lymphoid aggregates/follicles in Chinese patients with chronic hepatitis C. Am J Gastroenterol 94(4):1006-1011.

Migeon BR. 2006. The role of X inactivation and cellular mosaicism in women's health and sex-specific diseases. JAMA 295(12):1428-1433.

Mihm S, Fayyazi A, Hartmann H, Ramadori G. 1997. Analysis of histopathological manifestations of chronic hepatitis $\mathrm{C}$ virus infection with respect to virus genotype. Hepatology 25(3):735-739.

Mihm S, Frese M, Meier V, Wietzke-Braun P, Scharf JG, Bartenschlager R, Ramadori G. 2004. Interferon type I gene expression in chronic hepatitis C. Lab Invest 84(9):11481159.

Mihm S, Hartmann H, Fayyazi A, Ramadori G. 1996a. Preferential virological response to interferon-alpha $2 \mathrm{a}$ in patients with chronic hepatitis $\mathrm{C}$ infected by virus genotype $3 \mathrm{a}$ and exhibiting a low gamma-GT/ALT ratio. Dig Dis Sci 41(6):1256-1264.

Mihm S, Hutschenreiter A, Fayyazi A, Pingel S, Ramadori G. 1996b. High inflammatory activity is associated with an increased amount of IFN-gamma transcripts in 
peripheral blood cells of patients with chronic hepatitis $\mathrm{C}$ virus infection. Med Microbiol Immunol 185(2):95-102.

Mosnier JF, Degott C, Marcellin P, Henin D, Erlinger S, Benhamou JP. 1993. The intraportal lymphoid nodule and its environment in chronic active hepatitis $\mathrm{C}$ : an immunohistochemical study. Hepatology 17(3):366-371.

Oh DY, Baumann K, Hamouda O, Eckert JK, Neumann K, Kucherer C, Bartmeyer B, Poggensee G, Oh N, Pruss A, Jessen H, Schumann RR. 2009. A frequent functional toll-like receptor 7 polymorphism is associated with accelerated HIV-1 disease progression. AIDS 23(3):297-307.

Patzwahl R, Meier V, Ramadori G, Mihm S. 2001. Enhanced expression of interferonregulated genes in the liver of patients with chronic hepatitis $\mathrm{C}$ virus infection: detection by suppression-subtractive hybridization. J Virol 75(3):1332-1338.

Schott E, Witt H, Neumann K, Bergk A, Halangk J, Weich V, Muller T, Puhl G, Wiedenmann B, Berg T. 2008. Association of TLR7 single nucleotide polymorphisms with chronic $\mathrm{HCV}$-infection and response to interferon-a-based therapy. J Viral Hepat 15(1):71-78.

Schott E, Witt H, Neumann K, Taube S, Oh DY, Schreier E, Vierich S, Puhl G, Bergk A, Halangk J, Weich V, Wiedenmann B, Berg T. 2007. A Toll-like receptor 7 single nucleotide polymorphism protects from advanced inflammation and fibrosis in male patients with chronic HCV-infection. J Hepatol 47(2):203-211.

Schwabe RF, Seki E, Brenner DA. 2006. Toll-like receptor signaling in the liver. Gastroenterology 130(6):1886-1900.

Seki E, Brenner DA. 2008. Toll-like receptors and adaptor molecules in liver disease: update. Hepatology 48(1):322-335.

Sheppard P, Kindsvogel W, Xu W, Henderson K, Schlutsmeyer S, Whitmore TE, Kuestner R, Garrigues U, Birks C, Roraback J, Ostrander C, Dong D, Shin J, Presnell S, Fox B, 
Haldeman B, Cooper E, Taft D, Gilbert T, Grant FJ, Tackett M, Krivan W, McKnight G, Clegg C, Foster D, Klucher KM. 2003. IL-28, IL-29 and their class II cytokine receptor IL-28R. Nat Immunol 4(1):63-68.

Suppiah V, Moldovan M, Ahlenstiel G, Berg T, Weltman M, Abate ML, Bassendine M, Spengler U, Dore GJ, Powell E, Riordan S, Sheridan D, Smedile A, Fragomeli V, Muller T, Bahlo M, Stewart GJ, Booth DR, George J. 2009. IL28B is associated with response to chronic hepatitis $\mathrm{C}$ interferon-alpha and ribavirin therapy. Nat Genet 41(10):1100-1104.

Tanaka Y, Nishida N, Sugiyama M, Kurosaki M, Matsuura K, Sakamoto N, Nakagawa M, Korenaga M, Hino K, Hige S, Ito Y, Mita E, Tanaka E, Mochida S, Murawaki Y, Honda M, Sakai A, Hiasa Y, Nishiguchi S, Koike A, Sakaida I, Imamura M, Ito K, Yano K, Masaki N, Sugauchi F, Izumi N, Tokunaga K, Mizokami M. 2009. Genomewide association of IL28B with response to pegylated interferon-alpha and ribavirin therapy for chronic hepatitis C. Nat Genet 41(10):1105-1109.

Wietzke-Braun P, Manhardt LB, Rosenberger A, Uy A, Ramadori G, Mihm S. 2007. Spontaneous elimination of hepatitis $\mathrm{C}$ virus infection: a retrospective study on demographic, clinical, and serological correlates. World J Gastroenterol 13(31):42244229. 